\title{
INFLUENCE OF BARIATRIC SURGERY ON CIRCADIAN RHYTHM OF OBESE PATIENTS
}

\section{INFLUÊNCIA DA CIRURGIA BARIÁTRICA NO RITMO CIRCADIANO DE PACIENTES OBESOS}

\author{
José Fabiano Costa Justus' ${ }^{1}$, Antonio Carlos Ligocki Campos ${ }^{2}$, Fábio Quirillo Milléo ${ }^{3}$, \\ Marcos Ricardo da Silva Rodrigues ${ }^{4}$, Paulo Vinícius Svidnicki ${ }^{5}$, Elaine Vieira ${ }^{6}$. \\ ${ }^{1}$ Postgraduate program in Medecine, (Clinical Surgery) Federal University of Paraná - \\ UFPR, Curitiba, Brazil and State University of Ponta Grossa - UEPG. Av. Carlos Cavalcanti \\ 4748, Ponta Grossa/PR, 84030-900, Brazil. Phone: (42) 3220-3128. E-mail: jfcjustus@ \\ hotmail.com \\ ${ }^{2}$ Postgraduate program in Medecine, (Clinical Surgery) Federal University of Paraná - \\ UFPR, Curitiba, Brazil . E-mail: aclcampos@hotmail.com \\ ${ }^{3}$ Institute of Applied Research in Medecine - INSPAM, Ponta Grossa, Brazil. E-mail: \\ fabiomilleo@uol.com.br \\ ${ }^{4}$ State University of Ponta Grossa - UEPG, Ponta Grossa, Brazil. E-mail: marcos.rrod@uol. \\ com.br \\ ${ }^{5}$ State University of Ponta Grossa - UEPG, Ponta Grossa, Brazil. E-mail:_paulovini_pg@ \\ hotmail.com \\ ${ }^{6}$ Diabetes and Obesity Laboratory, IDIBAPS, CIBERDEM, Barcelona, Spain. E-mail: \\ evieira@ciberdem.org
}

Data de recebimento: $15 / 05 / 2013$

Data da aprovação: 20/06/2013

\begin{abstract}
Studies show a strong association between disturbances of circadian rhythms and the development of obesity and type 2 diabetes mellitus (T2DM). Disturbances of the biological clock due to sleep loss, for example, can lead to decreased insulin sensitivity and increased risk of obesity and type 2 diabetes. Bariatric surgery is an alternative strategy for weight loss and significantly reduces the mortality of obese patients. However, some patients have regained weight by some mechanism not yet understood. This weight regain is higher in patients with circadian disturbances due to changes in shift work. Given the importance of circadian rhythms in obesity, the present study is a literature review about the effects of bariatric surgery on the circadian pattern of hormones in obese patients.
\end{abstract}

Keywords: Circadian regulation. Hormones and adipokines. Bariatric surgery.

\section{RESUMO}

Estudos demonstram uma forte associação entre distúrbios dos ritmos circadianos e desenvolvimento de obesidade e diabetes mellitus tipo 2 (DM2). Alterações do relógio biológico por pouco sono, por exemplo, podem levar a decréscimo da sensibilidade à insulina e aumento do risco de obesidade e DM2. A cirurgia bariátrica é uma alternativa capaz de reduzir o peso e consequentemente a mortalidade desses indivíduos. Por outro lado, alguns pacientes apresentam reganho de peso por algum mecanismo ainda não 
José Fabiano Costa Justus, et al.

conhecido. Esse reganho de peso é maior em pacientes com distúrbios circadianos por alteração de turno de trabalho. Partindo disso, o presente trabalho é uma revisão de literatura a respeito dos efeitos da cirurgia bariátrica no padrão circadiano de hormônios e adipocinas em pacientes obesos.

Palavras-chave: Regulação circadiana. Hormônios e adipocinas. Cirurgia bariátrica.

\section{Introduction}

Physical inactivity and excess food intake are some causes of the worldwide epidemic of obesity and metabolic syndrome. A number of reports from clinical epidemiological studies have led to the hypothesis that one of the most important changes in the modern world that contributes to the pathogenesis of the metabolic syndrome involves disturbances of circadian rhythms. Lack of sleep or shift work can decrease insulin sensitivity and increase the incidence of visceral adiposity and type 2 diabetes. Interestingly, in the case of lack of sleep the circadian oscillations of hormones have been shown to be disrupted. Although it is known that some hormones exhibit circadian rhythms, not so much is known about whether they are disrupted in obesity and also if their levels can be normalized after bariatric surgery. Therefore, the aim of the present review is to give an overview of the literature about the effects of bariatric surgery on the circadian pattern of hormones from obese patients.

\section{Background}

\section{Circadian Regulation}

Numerous organisms have daily rhythms in their physiological and behavioral functions that are driven by circadian pacemaker cells located in the suprachiasmatic nucleus in the hypothalamus (LOWREY et al., 2004). The secretion of hormones such as insulin, leptin and cortisol, as well as lipid and carbohydrate metabolism, are a few examples of the many metabolic processes in our body that are subjected to circadian oscillations. For instance, circulating leptin concentrations exhibit a circadian pattern, with peaks during the night time in humans (SINHA et al., 1996; SAAD et al., 1998; PTITSYN et al., 2006). The pancreas increases the secretion of glucagon during the night, whereas it promotes an increase in insulin secretion during the day to maintain glucose homeostasis of the organism (BASS et al., 2010). However, ablation of the biological clock in certain tissues will cause opposing effects on metabolic functions at different times in the cycle under different nutrient conditions. Indeed, it was recently shown in mice that high fat diet feeding disrupts the circadian rhythms of insulin secretion (VIEIRA et al., 2012). Thus, circadian hormone oscillations are essential to maintain our physiological functions and to avoid the incidence of metabolic diseases.

\section{Circadian regulation in Obesity and Diabetes Mellitus}

In modern society, obesity is considered to be an alarming health problem. It reduces life expectancy and increases the rates of cancer, type 2 diabetes, heart disease and sleep disorders. Recently, new possible contributors have been identified as possible causes of obesity. It has been proposed that circadian disturbances trigger obesity and type 2 diabetes. Circadian disruption caused by long-term shift work has been associated with dislipidaemia and an increased risk of diabetes and cardiovascular disease (KNUTSSON, 2003) and circadian disruption caused by sleep loss can lead to a decrease in insulin sensitivity and increased risk of obesity and Diabetes Mellitus (SPIEGEL, 2005). Sleep loss has also been shown to increase the body max index, to increase the levels of ghrelin and to decrease leptin levels in humans (TAHERI et al., 2004). On the other hand, the circadian rhythms of adipokines, adiponectin and leptin have been shown to be blunted in obese subjects (YILDIZ et al., 2004). In healthy subjects, insulin secretion has well defined 24- hour oscillations, peaking in the early morning and declining during the 
night (BODEN et al., 1999). However, first-degree relatives of patients with $\mathrm{T} 2 \mathrm{D}$ have shorter insulin secretion cycles that lack real periodicity. Thus, disturbances in circadian rhythms and changes in the circadian rhythms of hormones may precede or be markers for metabolic diseases.

\section{Effects of bariatric surgery on circadian rhythms}

Pharmacotherapy and lifestyle intervention programmes fail to maintain long-term weight loss, principally in severe obesity, whereas bariatric surgery can maintain weight loss and decrease mortality rates (MACDONALD, 1997; Anderson et al., 2006). On the other hand, some obese subjects have a weight regain after bariatric surgery but the mechanism explaining this weight regain is still unknown (DEYLGAT et al., 2012). Interestingly, obese subjects that had disturbances in circadian rhythms due to shift work more frequently exhibited weight regain after bariatric surgery than non shift workers. These results indicate an intrinsic mechanism in the regulation of circadian rhythms that could not be corrected by bariatric surgery (KETCHUM et al., 2007).

Another study concerning the effects of bariatric surgery on circadian pattern showed that the effect of biliopancreatic diversion on the diurnal pattern of incretins differed markedly between patients with type 2 diabetes and normal glucose-tolerant subjects. For example, impairment of circadian GLP-1 secretion could not be overcome by biliopancreatic diversion in patients with diabetes but was reversed in normal glucose-tolerant subjects. Contrarily, circadian GIP secretion was blunted after the operation only in diabetic patients, suggesting a role of this incretin in insulin resistance and diabetes (DEYLGAT et al., 2009). These results highlight the importance of studying the circadian rhythms of hormones and their relationship with obesity. In addition, studies are needed to understand whether weight loss and improvements of metabolic parameters following bariatric surgery can correct disturbances in the circadian secretion of hormones in obese subjects. Thus, better understanding of the role of bariatric surgery on circadian rhythms in humans will certainly help to develop new strategies and therapies for the treatment of type 2 diabetes and obesity.

\section{Conclusion}

Studies have pointed out the relationship between circadian rhythms and the development of obesity. Not so much is known about whether bariatric surgery can change the circadian rhythms of hormones in obese subjects. In addition, it is not known whether the beneficial effects of bariatric surgery on weight loss and metabolic parameters are sufficient to normalize the circadian rhythms of hormones.

Therefore, to study the circadian rhythms of hormones before and after bariatric surgery could help to identify new factors involved in the pathogenesis of obesity.

\section{REFERENCES}

ANDERSON, J. W.; GRANT, L.; GOTTHELF, L.; STIFLER, L. T. Weight loss and long-term follow-up of severely obese individuals treated with an intense behavioral program. Int J Obes: v.31, p.488-493, 2006.

BASS, J.; TAKAHASHI, J. S. Circadian Integration of Metabolism and Energetics. Science, v.330, p.1349-54, 2010 .

BODEN, G.; CHEN, X.; URBAIN, J. L. Evidence for a circadian rhythm of insulin sensitivity in patients with NIDDM caused by cyclic changes in hepatic glucose production. Diabetes, v.48, p.2182-88, 1999.

DEYLGAT, B.; D'HONDT, M.; POTTEL, H.; VANSTEENKISTE, F., VAN ROOY, F.; DEVRIENDT, D. Circadian rhythms of GIP and GLP1 in glucose-tolerant and in type 2 diabetic patients after biliopancreatic diversion. Diabetologia, v.52, p.873-881, 2009.

DEYLGAT, B.; D’HONDT, M.; POTTEL, H.; VANSTEENKISTE, F.; VAN ROOY, F.; DEVRIENDT, D. Indications, safety, and feasibility of conversion of failed bariatric surgery to Roux-en-Y gastric bypass: a retrospective comparative study with primary laparoscopic Roux-en-Y gastric bypass. Surg Endosc, 2012.

KETCHUM, E. S.; MORTON, J. M. Disappointing weight loss among shift workers after laparoscopic gastric bypass surgery. Obes Surg, v.17, n.5, p.581-4, 2007.

KNUTSSON A. Health disorders of shift workers. Occup Med, v.53, p.103-08, 2003.

LOWREY P. L.; TAKAHASHI J. S. Mammalian circadian biology: elucidating genome-wide levels of temporal organization. Annu Rev Genomics Hum Genet, v.5, p.407-441, 2004. 
MACDONALD, K. G.; LONG, S. D.; SWANSON, M. S. et al. The gastric bypass operation reduces the progression and mortality of NIDDM. J Gastrointest Surg, v.1, p.213220, 1997.

PTITSYN, A. A.; ZVONIC, S.; CONRAD, S. A.; SCOTT, L. K.; MYNATT, R. L.; GIMBLE, J. M. Circadian clocks are resounding in peripheral tissues. PLoS Comput. Biol, v.2, n.16, 2006.

SAAD, M. F.; RIAD-GABRIEL, M. G.; KHAN, A.; SHARMA, A.; MICHAEL, R.; JINAGOUDA, S. D.; BOYADJIAN, R.; STEIL, G. M. Diurnal and ultradian rhythmicity of plasma leptin:effects of gender and adiposity. J Clin Endocrinol Metab, v.83, p.453-459, 1998.

SINHA, M. K.; OHANNESIAN, J. P.; HEIMAN, M. L.; KRIAUCIUNAS, A.; STEPHENS, T. W.; MAGOSIN, S.; MARCO, C.; CARO, J. F. Nocturnal rise of leptin in lean, obese, and non-insulindependent diabetes mellitus subjects. J Clin Invest, v.97, p.1344-1347, 1996.

SPIEGEL, K.; KNUTSON, K.; LEPROULT, R.; TASALI, E.; VAN CAUTER, E. Sleep loss: a novel risk factor for insulin resistance and Type 2 diabetes. J.Appl.Physiol, v.99, p.2008-19, 2005.

TAHERI, S.; LIN, L.; AUSTIN, D.; YOUNG, T.; MIGNOT, E. Short sleep duration is associated with reduced leptin, elevated ghrelin, and increased body mass index. Plos Medicine, v.1, n.3, p.62, 2004.

VIEIRA, E.; MARROQUÍ, L.; BATISTA, T. M.; CABALLERO-GARRIDO, E.; CARNEIRO, E. M.; BOSCHERO, A. C.; NADAL, A.; QUESADA, I. The clock gene Rev-erbalpha regulates pancreatic beta-cell function: modulation by leptin and high fat diet. Endocrinology, v.153, p.592-601, 2012.

YILDIZ, B. O.; SUCHARD, M. A.; WONG, M. L.; MCCANN, S. M.; LICINIO, J. Alterations in the dynamics of circulating ghrelin, adiponectin, and leptin in human obesity. Proc. Natl. Acad. Sci, v.101, p.10434-10439, 2004. 